\title{
TRANSPORT AND EMPLACEMENT OF THE 15.4 MA RHYOLITIC IGNIMBRITES FROM GUTÂI MTS., EASTERN CARPATHIANS, ROMANIA
}

\begin{abstract}
ALEXANDRINA FULOP ${ }^{1}$
ABSTRACT. The 15.4 Ma rhyolitic ignimbrites are the first volcanic products from Gutâi Mts. The study of their sedimentary structures reflects the mechanisms involved in the transport and emplacement of the parental flows, essential to inffering the style of eruption and the source evolution and location.

Primary sedimentary structures show massive deposits emplaced from mass flows, sequence of units showing the normal coarse-tail grading of the dense clasts and the reverse coarse-tail grading of the pumice clasts. They reflect concentrated laminar flows or dilute, subcritical flows emplaced by progressive aggradation.

Secondary sedimentary structures are represented by the eutaxitic texture or welding, cooling textures (columnar jointings, spherulitic textures) and gas-escape pipes. They assess the hot state deposition with low degree of fluidization, low cooling rates and gas-retention regime.

Ignimbrites are supposed to be emplaced as a single cooling unit, from the dense, bazal part of a maintained, stratified dilute pyroclastic current, in subcritical regime. This rheology, the temperature and volatiles regime is compatible with "boilingover" eruptive style and caldera collapse. The source location is suggested within Gutâi Mts area.
\end{abstract}

Key words: Gutâi Mts., rhyolitic ignimbrites, sedimentary structures, stratified dilute flow, subcritical flow regime, gas-retention regime, cooling unit, progressive aggradation, "boiling over", caldera collapse.

\section{Introduction}

Gutâi Mts. belong to the northern segment of the Romanian Eastern Carpathians inner volcanic arc. At the regional scale, they are incorporated by the Neogene volcanic arc of the Carpathians, edified as a consequence of complex subduction processes developed during Miocene in the Carpatho-Pannonian Region (Seghedi et al, 1998).

The dynamics of the tectonic processes is reflected by the wide range of petrotypes identified in Gutâi Mts. The sequence of eruptive pulses and quiescence periods developed between 15.4 - 7.0 Ma (Pecskay et al, 1995), simultaneously with sedimentation in adiacent basins.

Volcanic activity started $15.4 \mathrm{Ma}$ ago with magmatic explosions involving an acidic, rhyolitic magma. The ignimbrites overlain the Paleogene sedimentary deposits, covering an area of $20 \mathrm{~km}$ length and $10 \mathrm{~km}$ width, on the south-western part of the mountains. Large outcrops and tens of boreholes control ignimbrites spreading and thickness which decreases from $W$ to $E$, from $350 \mathrm{~m}$ to $30 \mathrm{~m}$ (Fulop, 2000) (Fig. 1). The study of the ignimbrites shows their rhyolitic composition and the lapilli grainsize. The geometry and the thickness distribution are valuable features useful in order to locate the source. 
This paper is focused on the sedimentary structures of the ignimbrites. They show the types of mechanisms involved in the transport and emplacement of parental flows. Flow rheology, volatiles and temperature regime, inffered from sedimentary structures, are steps in reconstructing source evolution.

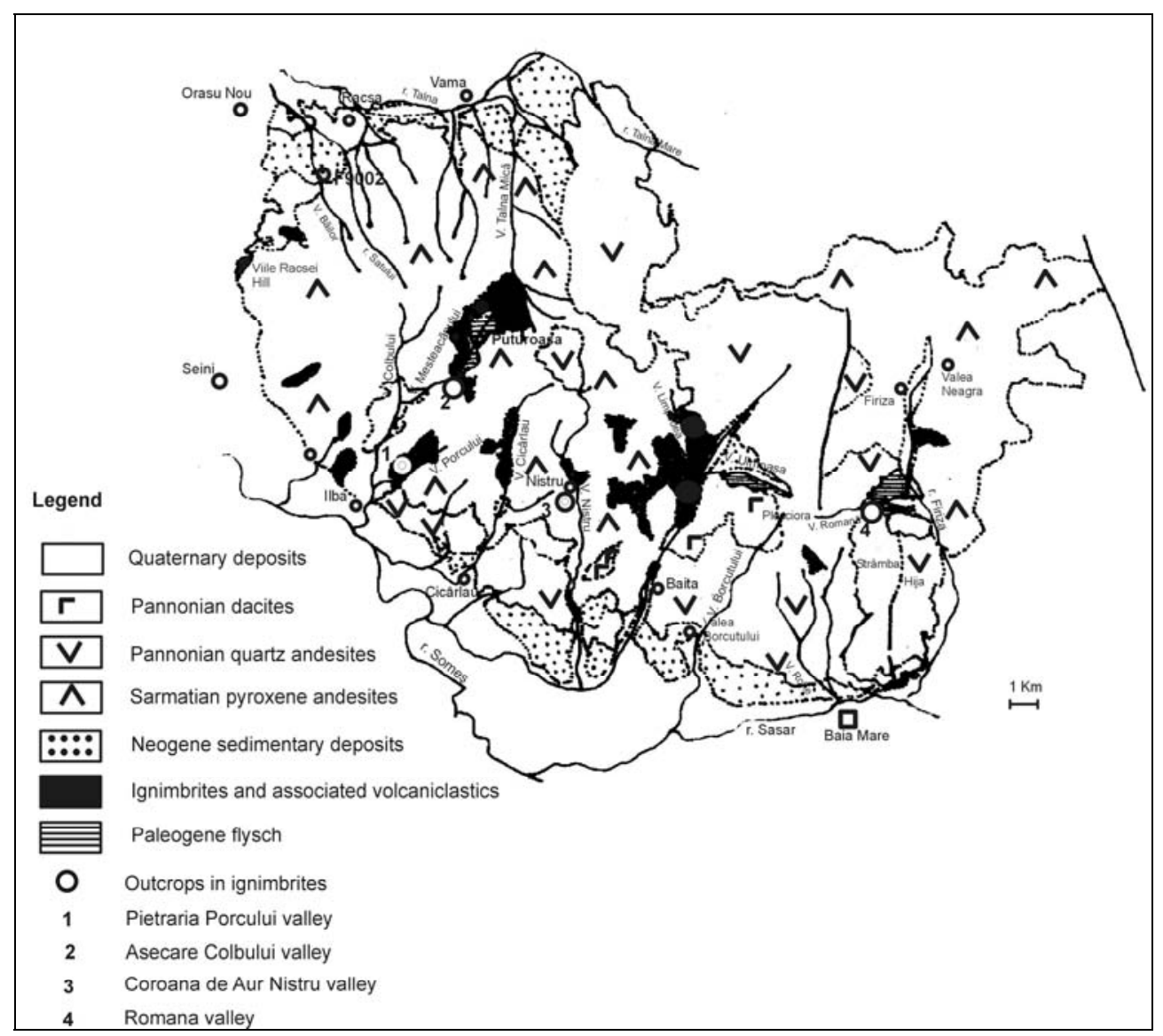

Fig. 1 Location of main outcrops of ignimbrites on geological sketch map of the south-western part of Gutâi Mts.

\section{Primary sedimentary structures}

Ignimbrites form stratified deposits, a thick unit composed of multiple, thinner units. They form a thinning and fining upwards sequence, showing the normal coarse-tail grading of the dense, lithic clasts. Each thin unit develops a massive structure and a weak reverse coarse-tail grading of the pumice clasts. The sequence of units corresponds to emplacement by progressive aggradation processes (Branney and Kokelaar, 1992) (Fig. 2; Fig. 3; Plate 1, photo 1). 


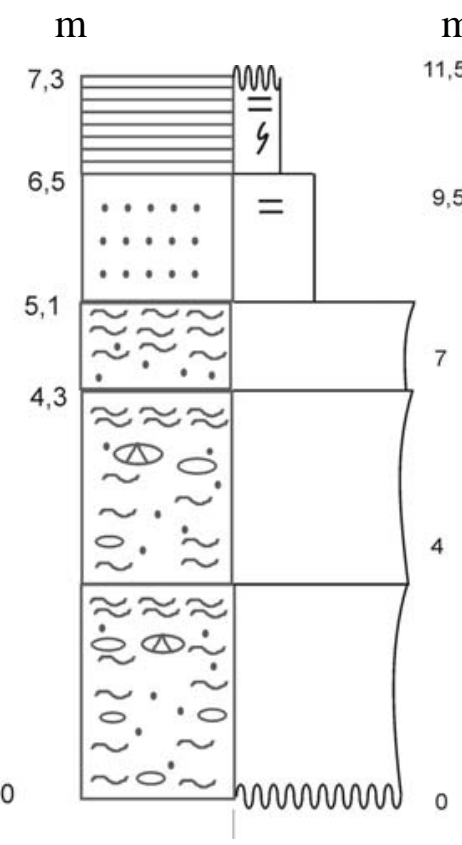

Fig. 2 Lithological column of ignimbrites in Pietraria Lupului valley outcrop, on Porcului valley (2) $\mathrm{m}$

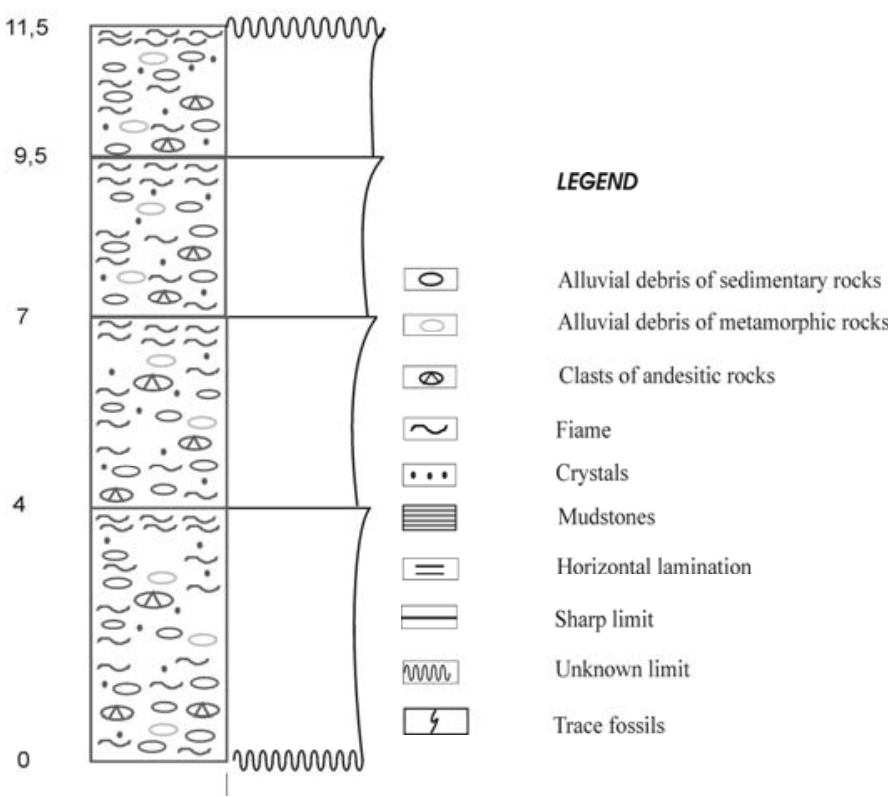

Massive structure, as dominant structural feature, is typical for mass flow deposits. Conceptual models regarding the ignimbrites flow rheology express two rheological extremes: the dense, laminar flow model (Freundt and Bursik, in Freundt and Rosi, 1998) and the dilute, turbulent flow model (Fisher et al, 1993). They are combined in the model of suspension currents, turbulent flows undergoing density stratification close to the source; the dense basal part emplaces the ignimbrite and the turbulent dilute upper part emplaces the overlain co-ignimbrite ash layer. The behaviour of suspension currents emphasized two regimes, based on the capacity of entraining air: the subcritical and respectively, the supercritical flow regimes (Bursik and Woods, 1996; Druitt, in Gilbert and Sparks, 1998; Freundt and Bursik, in Freundt and Rosi, 1998).

Primary sedimentary structures suggest laminar dense flows or turbulent dilute flows in subcritical regime. This is in accordance with the weak fluidization grading. The sequence of units emplaced by progressive aggradation records the rapid succession of flow units, successive pulses from a steady, maintained pyroclastic current (Druitt, in Gilbert and Sparks, 1998). 


\section{Secondary sedimentary structures}

The secondary sedimentary structures are represented by: welding lineation or eutaxitic texture, microscopical cooling textures, cooling columnar jointings and gas-escape structures.

The eutaxitic texture is represented by the horizontal, subparallel alignement of the flattened pumice clasts called fiame (Plate 2, photo 1; Plate 3, microphotos 1,2). The flattening ratios, calculated for a large number of samples (Fulop, in press), indicate the widespread character of "densely welded ignimbrites", according to Petersen in Smith (1980), or "high grade ignimbrites", according to Freundt (1998). Welding assesses the hot state deposition. It corresponds to a post emplacement load compaction under an overburden pressure, developed at high temperature. The almost uniform welding, distributed on the whole thickness, suggests the emplacement of a single cooling unit. The high intensity of welding suggests the volatiles-retention regime and the low degree of fluidization of parental flows; it is accepted at maximum $20 \mathrm{~km}$ away from the source, a distal unwelded facies being expected further (Freundt, 1998). The high temperature domain is preserved within $20 \mathrm{~km}$, but local variations are supposed to exist due to variations of the cooling rate (when alluvial clasts are incorporated or small amounts of air are entrained at the upper part of the flow).

Welding has major implications in flow rheology. The gas-retention regime involving low fluidization is compatible with dilute flows in subcritical regime. The dense, laminar flow model is excluded because it would restrict deposits to an area very close to the source, due to aggregation welding (Freundt, 1998). The supposed eruption temperature may be calculated admitting that it represents 1.3 minimum temperature of welding (Freundt, 1998; 1999). According to Sparks et al (1978), the temperature of welding for the rhyolitic ignimbrites is about $600-700^{\circ} \mathrm{C}$ and it corresponds to $800-900^{\circ} \mathrm{C}$ as temperature of eruption.

The cooling textures, significant from the point of view of the processes involved during emplacement, are represented by spherulitic textures identified under microscope. Spherulites show axiolitic textures, fans morphologies, pectinate textures and lithophysae (Plate 4, microphotos 1,2). The mineralogical assemblage cannot be determined under microscope but it seems to be composed of alkali feldspar, tridymite/cristobalite, plagioclase. The textures corresponds to the spherulitic stage of devitrification of the acide, rhyolitic glass (Lofgren, 1971, in McPhie et al, 1993; McArthur et al, 1998). A very low cooling rate is supposed, with maintained high temperatures; they are preserved during ignimbrites emplacement, when hot pumice is plastically deformed and involves spherulites nucleation in small vesicles. When spherulites crystalize, volatiles exolve and vesicles are expanding forming lithophysae (McPhie et al, 1993; McArthur et al, 1998).

Spherulites are concentrated in the middle part of ignimbrite deposits, in the western area of outcropping. They suggest conditions allowing the preservation of high, close to liquidus temperatures. Such conditions are compatible with high eruption temperatures, with minimum heat loss in the eruption column and during the flow and indicate the source proximity. 
Cooling columnar jointings have been rarely identified. In outcrop 3 , Coroana de Aur, Nistru valley (Fig. 1), vertical joints separate prismatic units, $1.40 \mathrm{~m}$ wide (Plate 1, photo 2). They assess the hot state deposition of a highly cohesive material and are associated with increasing viscosity and contraction during cooling.

Gas-escape structures have been identified in a single outcrop, 4, on Romana Valley (Fig. 1). They are $25-30 \mathrm{~cm}$ long and $1-2 \mathrm{~cm}$ wide and form elongate, vertical or inclined structures in the lower part of deposits (Plate 2, photo 2). Gas-escape pipes accumulates crystals, pumice clasts and xenoliths with an average grainsize of $1 \mathrm{~cm}$. Their presence is related to fluidization of already emplaced ignimbrites and the concentration in the lower part of deposits suggests an external source of gas (air entrained by flow, vegetation, water, alluvial sediments incorporated by the flow). The very rare gas-escape pipes are compatible with volatile-retention regime and weak fluidization (Sparks et al, 1999).

The secondary sedimentary structures reflect ignimbrites emplacement at very high temperatures allowing areal extent of strong welding, low cooling rates subordinately fluctuating and correspond to dilute flows, in subcritical regime (Bursik and Woods, 1996; Freundt, 1998, 1999). This is in accordance with the model of turbulent, stratified suspension current and the emplacement of the ignimbrites from the dense, basal flow. Welding is limited within $20 \mathrm{~km}$ away from the source and it suggests the source location in the area of Gutâi Mts. The high temperature regime is compatible with low eruption columns suggesting the "boiling over" style leading to caldera collapse (Freundt, 1998).

\section{Conclusions}

Flow rheology, mechanisms of emplacement, volatile and temperature regimes are reflected by the primary and secondary structures of the ignimbrites. They are useful in order to reconstruct the style of eruption and the type of source.

The primary sedimentary structures, identified in outcrops, are the massive structure and the grading. Deposits form thinning and fining upwards sequence, each of its unit showing massive structure and weak grading. They suggest mass flow deposits emplaced from the basal, dense layer of a maintained, density stratified suspension current, by progressive aggradation.

The secondary sedimentary structures have been identified in outcrops and by the microscopical study.

The welding lineation or the eutaxitic texture, noticed in outcrops and confirmed by the microscopical study, assesses the hot state deposition and the gas-retention regime of the parental flows. They suggest dilute flows in subcritical regime, preserving the high temperatures during emplacement and post emplacement load compaction. The areal distribution of welding suggests the location of the source within a distance of $20 \mathrm{~km}$. The calculated temperature of eruption is around $800-900^{\circ} \mathrm{C}$. A low eruption column is suggested, the "boiling over style" and possibly the final caldera collapse. 


\section{ALEXANDRINA FULOP}

Microscopical cooling textures such as spherulites and lithophysae are compatible with the high temperature regime, close to liquidus. Their location is very important in assessing the source proximity.

Cooling columnar jointings confirm the high temperatures and the scarse gas-escape pipes are in accordance with the subcritical flow regime, preserving the volatiles and the high temperature.

Ignimbrites record therefore magmatic explosions, low fountain boiling over and steady, maintained suspension pyroclastic current. It moved as a turbulent flow, underwent density stratification and emplaced the ignimbrites from the dense, basal underflow, by proggressive aggradation processes.

\section{REFERENCES}

Bursik M.I., Woods A.W., 1996: The dynamics and thermodynamics of large ash flows, Bull. Volcanol. 58: 175-193.

Branney J., M., Kokelaar P., 1992 - A reappraisal of ignimbrite emplacement: progressive aggradation and changes from particulate to non-particulate flow during emplacement of high-grade ignimbrite; Bull. Volcanol., vol 54, pp. 514

Druitt T. H., 1998: Pyroclastic density currents, in Gilbert J.S.O Sparks, R.S.J. (eds) "The Physics of Explosive Volcanic Eruptions", Geological Society, London, Special Publication, 145, 145-182.

Fülöp A., in press: Morphology of pumice clasts and glass shards of the Rhyodacitic volcaniclastics from Gutâi Mountains: involved processes. Rom. J. Mineralogy

Fülöp A., 2000: Analiza secvențială a piroclastitelor acide din baza complexului vulcanic al Munților Gutâi; reconstituiri paleovulcanice şi paleosedimentologice. Teza de doctorat, Universitatea Bucureşti

Fisher R.V., Orsi G., Ort M., Heiken G., 1993: Mobility of large - volume pyroclastic flow - emplacement of the Campanian ignimbrite, Italy, Journal of Volcanol. and Geotherm. Research 56: 205-220, Elsevier, Amsterdam.

Freundt A., 1998: The formation of high-grade ignimbrites, I: Experiments on lowconcentration transport systems containing sticky particles Bull. volcanol. 59: 414-435.

Freundt A., Bursik M. I., 1998: Pyroclastic flow transport mechanisms, in Developments in volcanology 4: "From magma to tephra-modelling physical processes of explosive volcanic eruptions" Freundt A. and Rosi M.(eds.), Elsevier, 173-245

Freundt A., 1999: Formation of high-grade ignimbrites Part II. A pyroclastic suspension current model with implications also for low-grade ignimbrites, Bull. volcanol. 60: 545-567.

McArthur A.N., Cas R.A.F., Orton G.J., 1998: Distribution and significance of crystalline, perlitic and vesicular textures in the Ordovician Garth Tuff (Wales), Bull. Volcanol. 60: 260-285.

McPhie J., Doyle M., Allen R., 1993: Volcanic textures - A guide to the interpretation of textures in volcanic rocks, Centre for Ore Deposits and Exploration Studies, Univ. of Tasmania, Australia. 
Pécskay Z., Edelstein O., Seghedi I., Szakács A., Kovacs M., Crihan M., Bernad A., 1995: K-Ar datings of Neogene-Quaternary calc-alkaline volcanic rocks in Romania. Acta Vulcanologica, 7,53-62.

Peterson W., D., 1979: Significance of the flattening of pumice fragments, Geol. Soc. of America, special paper 180.

Seghedi I., Balintoni I., Szakács A., 1998: Interplay of tectonics and neogene postcollisional magmatism in the intracarpathian region Lithos.

Smith R. L., 1980: Ash-flow tuffs: their origin, geologic relations and identification; zones and zonal variations in welded ash flows. Professional papers 354 F. 366, special publication no 9.

Sparks R.S.J., Wilson L., Hulme G., 1978: Theoretical modeling of the generation, movement and emplacement of pyroclastic flows by column collapse, J. Geophys. Res., 83: 1727-1739.

Sparks R.S.J., Tait S.R., Janev J., 1999: Dense welding caused by volatile resorption, Journal of the Geol. Soc. London, 156: 217-225.

\section{Plate 1:}

- $\quad$ Photo 1: Ignimbrites sequence in Asecare outcrop (2), Colbu valley;

- $\quad$ Photo 2: Columnar jointings in Coroana de Aur outcrop (3), Nistru valley.

Plate 2:

- $\quad$ Photo 1: Eutaxitic texture in an ignimbrite (drill core);

- $\quad$ Photo 2: Gas-escape pipes from Romana valley outcrop (4).

\section{Plate 3:}

- $\quad$ Microphoto 1: Eutaxitic texture of a lapilli tuff; $q=$ quartz; plg = plagioclase; $\mathrm{f}=$ fiame, microfiame; $\mathrm{m}=$ matrix; $\mathrm{N} \mathrm{II} ; 60 \mathrm{X}$;

- $\quad$ Microphoto 2: Eutaxitic texture of a lapilli tuff; plg = plagioclase; bi = biotite; $\mathrm{f}=$ fiame; $\mathrm{m}=$ matrix; $\mathrm{N}+, 60 \mathrm{X}$.

\section{Plate 4:}

- $\quad$ Microphoto 1: Lithophysae in a welded lapilli tuff; $s$ = spherulites; se = cavities filled with sericite; $m=$ devitrified matrix; $N+; 100 X$;

- $\quad$ Microphoto 2: Spherulitic textures within fiame; $s=$ spherulites; $m=$ devitrified matrix; $\mathrm{N}+; 100 \mathrm{X}$. 


\section{Plate 1}
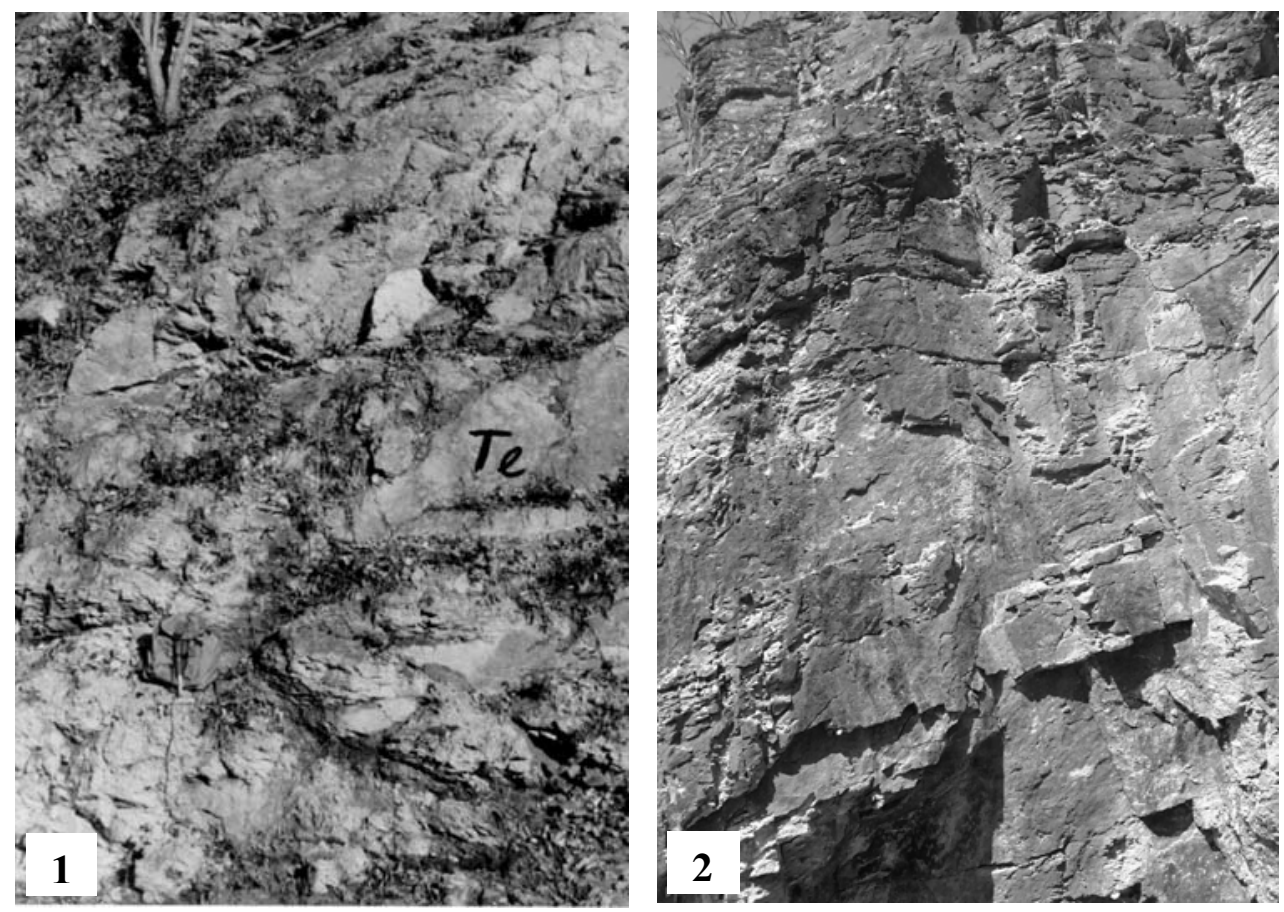
TRANSPORT AND EMPLACEMENT OF THE 15.4 MA RHYOLITIC IGNIMBRITES FROM GUTÂI MTS. ...

\section{Plate 2}
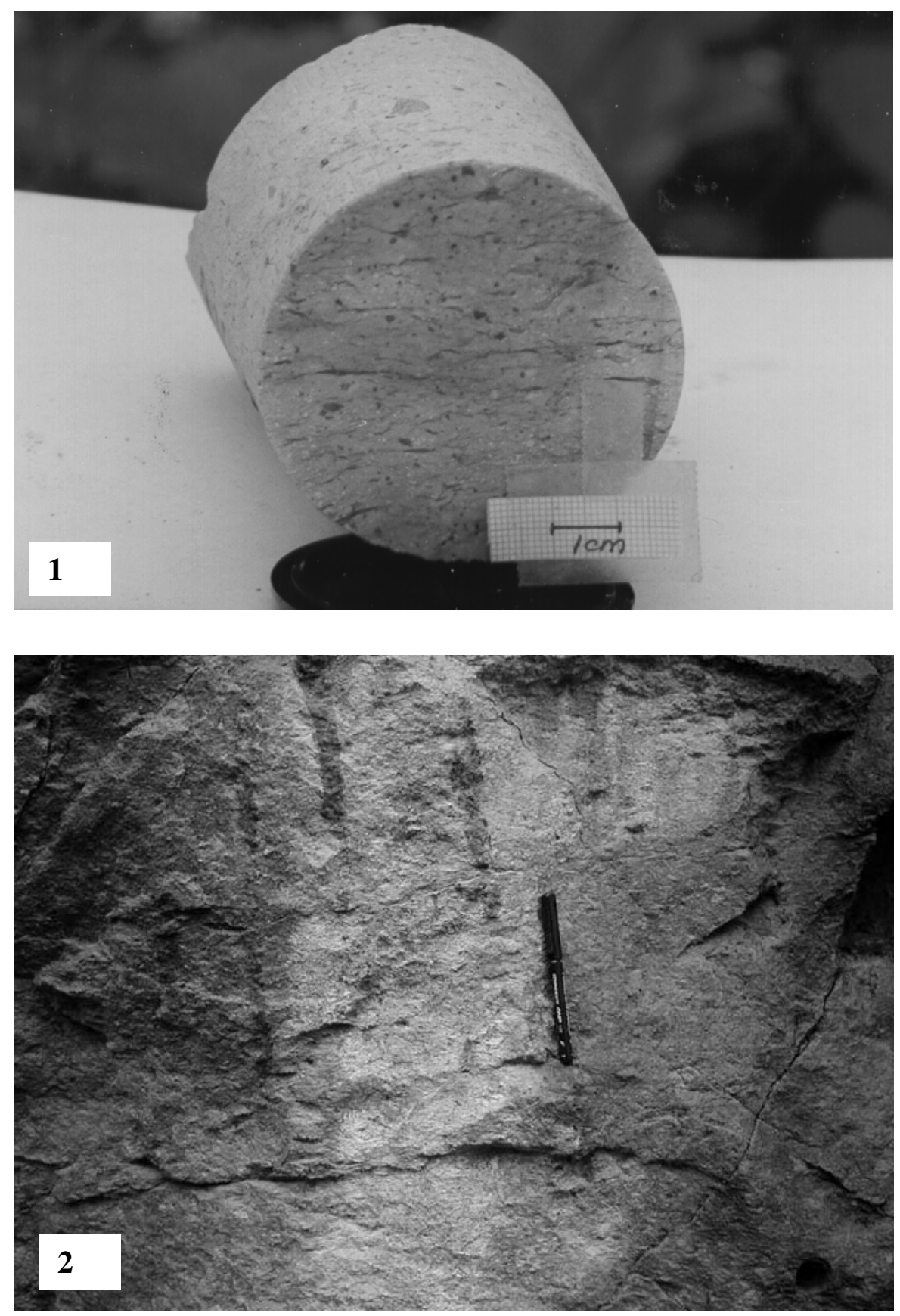


\section{Plate 3}
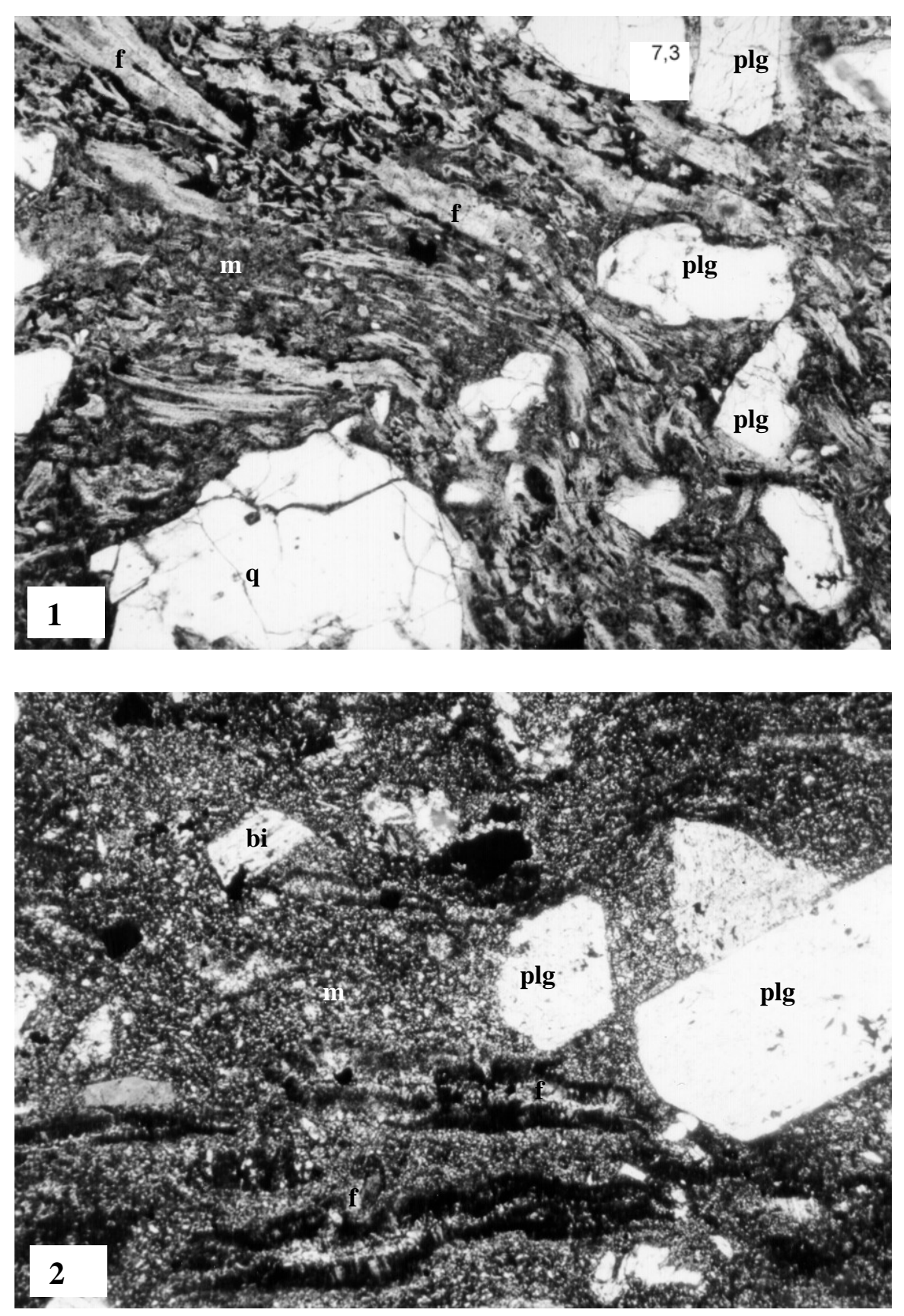


\section{Plate 4}
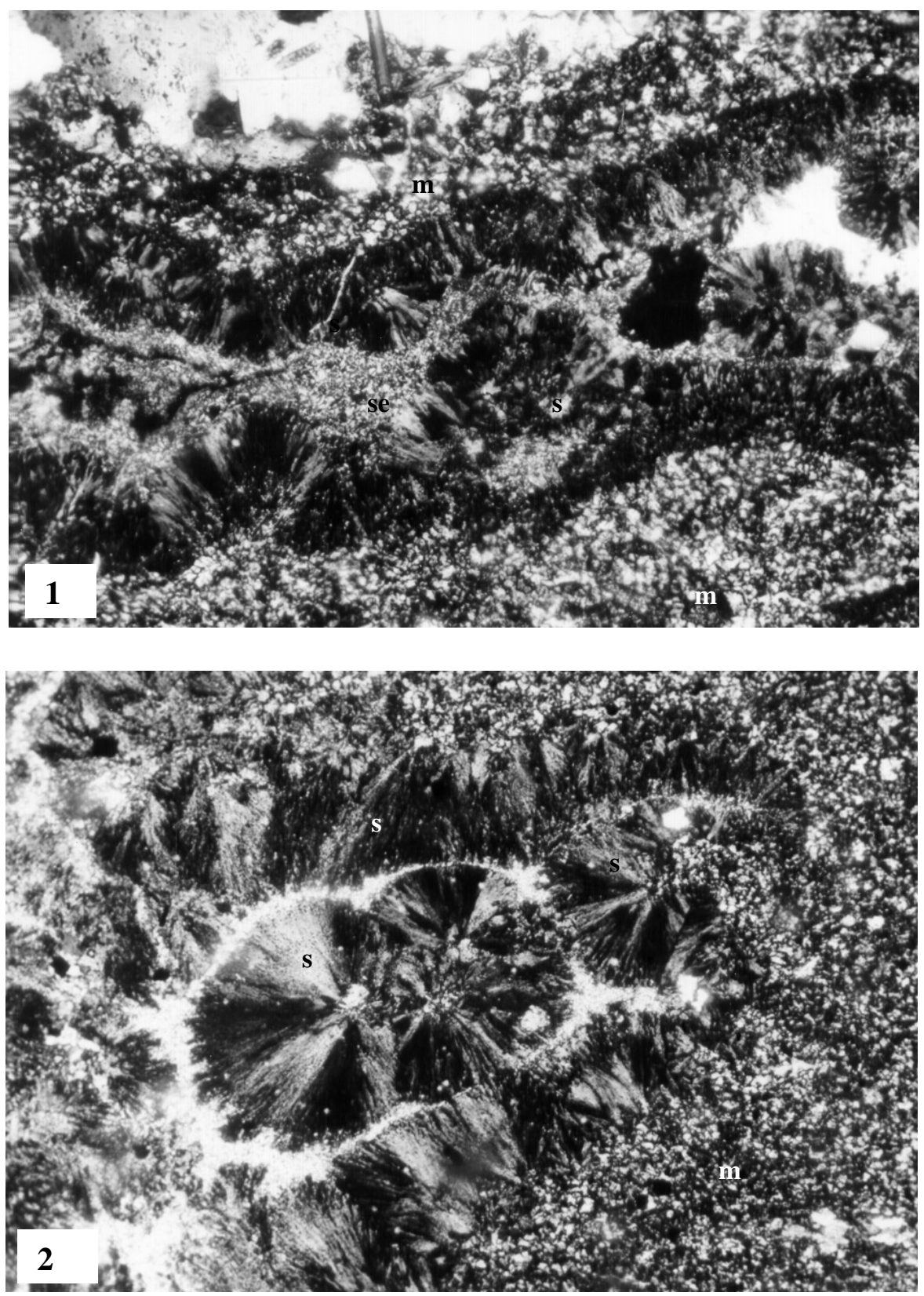